\title{
ANTONIO GALA, EL CONCEPTO DE FIDELIDAD EN UN INTELECTUAL
}

\section{Françoise Dubosquet Lairys}

\author{
Universidad de Rennes 2 (Francia)
}

Cuando empecé a trabajar sobre el posfranquismo, más precisamente sobre el papel de los intelectuales en la prensa, una referencia se impuso casi de repente: Antonio Gala. Aparentemente desconocido en mi tierra, su primera obra de teatro, Los verdes campos del Edén había sido leída en una presentación pública en París, tal como El sol en el hormiguero, pero ninguna de ellos había sido representada. Tuvimos que esperar al otoño de 1996 para tener la primera traducción de una obra suya, por fin publicada: El manuscrito carmesí (Mémoires Ecarlates, París: éd. Lattés, 1996), percibiéndose un cierto rechazo por parte de nuestros universitarios en acercarse a su obra. Por otro lado, la figura de Antonio Gala se presentaba más allá de los Pirineos como una referencia incontestable en esta España del posfranquismo, una España en marcha, en busca de una nueva y verdadera identidad. Sin embargo, aparecía y sigue apareciendo como una figura muy polémica y controvertida y de cierta forma, atípica, y el mundo intelectual español parecía 
compartir ese mismo recelo o timidez ${ }^{1}$ frente a este autor y su obra, pese a que sea ya un dramaturgo reconocido desde 1963 (Premio Nacional de Teatro Calderón de la Barca) y Premio Nacional de Literatura. «Es como una misteriosa ley matemática y con flema empírica», como lo constata Juan Cueto, ya que «...el silencio intelectual aumenta a medida que aumentan las ovaciones populares...» (Gala, 1983a: 15). Ese aparente desfase entre éxito popular y reconocimiento por el mundo intelectual me llamó muchísimo la atención y fue sin duda uno de los acicates que me condujeron al descubrimiento de la obra y personalidad de Antonio Gala. Despertaba muchas interrogaciones sobre el éxito, el concepto de obra o autor popular, sobre el sitio particular que ocupa Antonio Gala en el mundo de la creación española, tan justamente interpretado por su amigo, el poeta José Infante, por el título de su libro: Antonio Gala, un hombre aparte (Infante, 1994).

La primera prueba tangible del éxito del autor fue y sigue siendo su número de lectores. Desde la publicación de sus Charlas con Troylo en 1980 (publicación de sus artículos en El País bajo este título entre 15/7/79-16/11/80) hasta su última novela la Regla de tres, publicada en 1996, pasando por El manuscrito carmesí, premio Planeta 1990, Antonio Gala no dejó de estar presente en los primeros eslabones de las listas de ventas. Sus obras de teatro conocen un éxito de taquilla, tal como su participación en El País Semanal desde 1979, El Independiente (13/6/87-9/6/89) o El Mundo más tarde (1989), que demuestran el interés por parte de estos medias y de sus lectores, como ya lo confirmaba Juan Cueto en 1983: «Hoy por hoy, Antonio Gala es el escritor de mayor éxito popular. Sus obras de teatro baten todos los records de taquilla y se reestrenan sin cesar y sin excepción, sus artículos habituales en la prensa provocan una avalancha de correo; sus intervenciones públicas constituyen verdaderos acontecimientos de muchedumbre, sólo comparables a los que suelen protagonizar cantantes, futbolistas, toreros o estrellas de cine, en fin, la presencia del autor ante las cámaras de televisión o los micrófonos de la radio hacen subir la atención instantáneamente y siempre es garantía de espectáculo cultural. Que yo sepa con las estadísticas en la mano, nunca en la historia reciente de este país un profesional de la literatura, ha logrado mayores índices de audiencia como se dice en la jerga de los medios

1 Sin embargo hay que citar los excelentes estudios sobre el autor de los profesores: Carmen Díaz Castañón, Fausto Díaz Padilla, Ana Padilla Mangas, José Romera Castillo, Isabel Martínez Moreno... Sobre este asunto, cf. lo señalado por J. Romera Castillo (1996). 
de comunicaciones...» (Gala, 1983a: 13). Impresión confirmada por Andrés Amorós, en su Diario cultural, quien compara el movimiento de la muchedumbre el día en el que el autor firmó sus Charlas con Troylo en el Retiro, con «la espuma de una cacerola al fuego por todos los alrededores..» y añade «He oído a un chico preguntar si es que venía el Rey, lo único que se le ha ocurrido ante semejante follón...» (Amorós, 1983). Pasando los años, la imagen pública de Antonio Gala no dejó de afirmarse, pero siempre de manera singular. Así que vamos a intentar en estas páginas entender las razones de tal éxito, definir esta singularidad que hace de Antonio Gala, un hombre aparte, y acercarnos a la personalidad del autor tal como a la riqueza de su creación.

\section{¿CÓMO EXPLICAR TAL ÉXITO?}

Su éxito se forjó a lo largo de los años 60: Accésit del Premio Adonais de poesía a finales de los años 50 con Enemigo íntimo; obtiene en 1963 el Premio Nacional de Teatro por su obra Los verdes campos del Edén, y ese mismo año el Premio Las Albinas por su relato Solsticio de invierno, recibe en 1972 el Premio Nacional de Literatura por su obra Los buenos días perdidos, para no citar más que algunos signficativos. En 1976 ya era conocido por su pluma acerada y libre, en efecto, el 26 de mayo los medias recibieron el anuncio de su asesinato, - cabe decir que sus relaciones con la censura eran tensas: su serie televisiva Paisaje con figuras había sido prohibida por Arias Navarro al cuarto episodio, y la salida de su artículo, titulado «las viudas» había provocado su procesamiento y el secuestro de la revista Sábado Gráfico (n. ${ }^{\circ} 988$ ), y padecía de unas constantes amenazas de muerte-, sin embargo, su reconocimiento popular estalla verdaderamente en 1978 con sus crónicas de $E l$ País, periódico «fetiche» de la Transición tituladas Charlas con Troylo. Claro, conviene subrayar que surgió en un momento determinado de la historia de España y de la carrera del autor, Antonio Gala escribe en la prensa desde los años $60^{2}$, o sea que el éxito que «estalló» con las publi-

2 De manera espóradica al principio: en Arriba, en 3/9/59-10/12/60 con las series de artículos titulados «En torno a bebidas internacionales; 1966-67, en Pueblo con «Tercera página» $y$ en 1970, con la serie de las «Cartas norteamericanas»; 07/73-07/78 en Sábado Gráfico bajo el título de «Texto y Pretexto» entre mayo y septiembre 1977, en la revista Repórter con «Verbo transitivo» ; 09/77 -1/78, en Primera Plana con «El color de las horas» y bajo el título de «Las citas históricas» en Actualidad Española 
caciones de sus Charlas con Troylo no puede entenderse sin el contexto particular del posfranquismo y más precisamente de la Transición, y la maduración de la obra galiana.

\section{EL CONTEXTO}

Los años 70 marcan profundamente el destino de España: la evolución ideológica y económica del país, y una necesaria adaptación del régimen, la muerte del viejo dictador en el 75, referéndum de reforma política, vuelta de la democracia, elecciones generales de 1977 y proclamación de la nueva Constitución de 1978, por citar algunos hechos importantes. Si el establecimiento de la democracia aparece lógico como resultado de la mutación no dejaba de plantear muchas interrogaciones y dudas. Primero porque no hubo ruptura con el sistema franquista ya que el nuevo sistema que se instaura a la muerte del viejo dictador fue elaborado por el régimen anterior y las cortes orgánicas. Fue un sector del aparato político el que elaboró, aprobó y cumplió con la estrategia que tenía que llevar a la democratización. Segundo, la Transición fue pacífica porque resultó de una especie de negociación. Lo que condicionó y sigue condicionando su actual desarrollo. Dentro de este marco, Antonio Gala se situará siempre como uno de los componentes entre millones de otros de esta España del posfranquismo, desorientada y decidida al mismo tiempo, una España tal como la presenta Juan Cueto, compuesta de «seres urgidos de líderes más espirituales que políticos, huérfanos de modelos carismáticos donde reflejarse o apoyarse por unos instantes y faltos de códigos que den respuestas a las mil angustias cotidianas de las sociedades modernas...» (Gala, 1983a).

Las Charlas con Troylo, y las dos series siguientes En Propia mano y Cuaderno de la Dama de Otoño, así como su creación teatral: La trilogía de la libertad ${ }^{3}$, tienen como telón de fondo el proceso de

entre enero de 1978 y marzo 1978. Después empezó en 1978 su colaboración con $E l$ País: 22/7/78-16/11/80 «Charlas con Troylo»; 1/81-9/1/83, «En Propia Mano»; 9/10/83-22/9/85, «Cuaderno de la Dama de Otoño»; 2/2/86-27/12/87, «Dedicado a Tobías»; 23/10/89-18/10/90, «La Soledad sonora»; 24/2/91- 4/4/93, «A quien conmigo va», 24/4/93- 6/95, «Carta a los herederos"; y ahora «La casa sosegada». Paralelamente escribió en $E$ Independiente (1988-90) «La proa» y luego «La Tronera», serie que sigue publicardo en $E l$ Mundo, después de la desaparición de El Independiente.

3 Que se compone de tres obras: Petra Regalada, La vieja señorita del Paraíso y El cementerio de los pájaros, que invitan a una reflexión sobre la libertad, cómo «se trenzan el apasionado deseo y el apasionado temor a la libertad...» 
transición, con sus esperanzas y sus angustias, con su reaprendizaje de la democracia en el cual cada uno tiene que recobrar y asumir su responsabilidad y papel, sea simple ciudadano o miembro del ejército, es un momento clave de la historia de España, cuando los diversos intentos de golpe (23-F y Galaxia), las presiones anti-democráticas de la extrema-derecha, extrema-izquierda o de extremo-nacionalismo peligran la nueva constitución. Las series siguientes como Dedicado a Tobias, la Soldedad Sonora, A quién conmigo va, las más recientes Cartas a los herederos y la última La casa sosegada, o sus obras teatrales como, por ejemplo, Séneca o el beneficio de la duda ${ }^{4}$ interesante reflexión sobre el poder, acompañan la postransición, las desilusiones y en cierta forma, la banalización de los logros democráticos. $E l$ País se ha vuelto ya el periódico del «establishment», una verdadera institución, los socialistas en el poder durante cuatro legislaturas, tres con mayoría absoluta, profesaron un pragmatismo declarado, lejos del mensaje ético proclamado en su programa, lejos de las promesas y de las ilusiones del otoño del 82, que compartió el autor con los 10 millones de sus compatriotas. La Proa y después La Tronera, «billet d'humeur», publicados en $\mathrm{El}$ Independiente durante su vida demasiado corta y después en El Mundo, serán otra tribuna, ésta claramente política, de reflexión o invitación a la reflexión en un país sacudido por los escándalos.

\section{LOS MEDIA:}

Estas relaciones con los media son también decisivas: a principios de la transición política, el autor eligió deliberadamente dejar los escenarios para consagrarse a colaboraciones más mediáticas: «Me doy cuenta de que la manera de comunicar es la prensa, todavía más que el teatro, porque hay gente que no va al teatro y que sin embargo, sí lee, y la televisión para comunicar de verdad con el pueblo... el interés en escribir en una prensa muy leída, y la televisión son porque los considero como dos métodos inmediatos de conectar con el pueblo...» (Dubosquet Lairys, 1989). En una época en la que la televisión

4 «En una época, cuya decadencia, cuya corrupción general, cuya sensación de agotamiento la hacen tan semejante a la nuestra, hay un hombre en Córdoba ... que personifica las tentaciones que el poder plantea a la ética, y el contagio con que la amoralidad asalta a la virtud...» (Gala., 1987: 49). 
se impone como primera forma de comunicación (o ¡incomunicación!), elemento central de todo hogar, Antonio Gala escribirá para TVE, un amplio repertorio que le va a proporcionar muchísima popularidad, en el que se destacan: Al final la esperanza; 4 conmemoraciones: Eterno Tuy, Auto del Santo Reino, Oratorio de Fuenterrabía, Retablo de Santa Teresa; y para celebrar el año compostelano: Cantar de Santiago para todos; Las tentaciones y dos interesantes series tituladas: Si las piedras hablaran y Paisaje con figuras, con las cuales se propuso contar a sus compatriotas su historia, como lo confiesa Gala: «he procurado que por lo menos, conozcamos algunas cosas. Cosa de este sitio en que vivimos y que se llama en general España. Cosas de gentes que nos han hecho ser como somos; de españoles que nos fueron haciendo así: españoles...» (Gala, 1985: 12). Esta voluntad se corresponde con una preocupación fundamental: «me parece de verdad esencial que el español reconozca su pasado para que aprenda a convivir con su presente y con su futuro. El pasado se nos ha enseñado de manera muy mala, de una manera triunfalista y falsa. Los españoles no conocen como han llegado a ser lo que son, entre otras cosas porque no son, porque no saben lo que son...» (Gala, 6/4/88). Fundamentalmente, se trata de aprehender el pasado para vivir y asumir el presente. Tema galdosiano por excelencia. El error básico de tantos españoles sería negar la realidad, oponerse a lo que ha sido la Historia.

\section{UNA HISTORIA COMÚN:}

Antonio Gala comparte con sus compatriotas una historia común: nacido en 1936, nos recuerda de manera precisa, por supuesto, la guerra: «Nací cuando nació la guerra, mi vida es la posguerra...»" (Gala, 24/8/86), quedando marcado por esa terrible experiencia: «mi familia me apartó hacia los libros... pero olí la sangre y lo que es peor, creí que era el olor natural del mundo. Nací con este olor» (Gala, 24/8/86). La guerra ya no aparece más que como pesadilla lejana, sin embargo de estos acontecimientos nació la España actual; su realidad política, económica y social es el resultado de este pasado fraticidio y totalitario. Sin duda alguna, el recuerdo de esta guerra fraticida pesó muchísimo en la elección consensual de la transición. No se pueden borrar cincuenta años de la memoria colec- 
tiva, cincuenta años de condición de existencia particular, hecha de temores, insatifacciones y contradicciones. Estos cincuenta años determinaron la formación de los españoles de hoy, y Antonio Gala es un ejemplo de esa generación nacida, educada en ese contexto particular, una sociedad herida tal como nos señala el autor: «Yo, por ejemplo, nací cuando la guerra. No tropecé con ella. Ni fui herido de bala. Pero sí, me encontré con una sociedad herida de bala...» (Dubosquet Lairys, 1989). Una sociedad y un país que Antonio Gala rehusó a abandonar: «A mí no me echan» y se quedó tal como lo recuerda Francisca Aguirre: «Antonio tenía razón, a nosotros no nos echaban, nosotros nos quedabamos. $Y$ nos quedamos, Antonio con su alegría desesperada (entonces, la alegría de Antonio era como un título de aquel cuento de Saroyan: como un cuchillo, como una flor, como absolutamente nada en el mundo), con sus poemas, sus relatos... su hambre, nuestra hambre...» (Aguirre, 1995). En efecto, Antonio Gala no perteneció a la generación del exilio, sino a la que se quedó en España y que intentó, a partir de los canales de expresión que permitía la censura, expresarse y contribuir a la creación que, pese a sus esfuerzos, la dictadura no podía totalmente ahogar.

Además lo que aparece claramente en el estudio de sus artículos, es el extraño paralelo entre la vida del autor, su experiencia personal y la historia de España de estos últimos cincuenta años. Nace en 1936, vive todo el periodo franquista, conoce el traumatismo de la muerte de un padre de autoridad absoluta y el difícil aprendizaje de la libertad individual, comparte la euforia, las angustias y las incertidumbres de sus compatriotas frente a la muerte del caudillo, frente al nacimiento de una España democrática que devuelve a cada uno el derecho, la obligación, la responsabilidad de participar en esta transformación. Lo que dio un matiz todavía más personal en su manera de aprehender la historia inmediata.

\section{LOS TEMAS}

Si la sociedad sirve de telón de fondo al conjunto de la obra galiana, sociedad contemporánea o trascendida por la historia, el eje central es el ser humano. 
Un ser a la búsqueda de sí mismo en una sociedad en la que la mayor parte del tiempo en vez de ayudarle en su propia realización, lo angustia, lo aprisiona en sus ortopedias, lo deforma. La poesía, los relatos, los artículos, el teatro, las sinopsis o la novela no tienen otra meta que participar en esta reflexión de cada ser humano frente a su destino. Así si su poesía habla del amor y desamor, de sus muertes o traiciones, los relatos evocarán la amistad y la separación de seres; los artículos, las angustias de una sociedad en busca de nuevas referencias en este final de siglo, frente a problemas tan diversos que van del terrorismo, pasando por la insumisión o la objeción de conciencia a una nueva ética -reflexión sobre el divorcio, el aborto, las drogas: tres asuntos, temas de debate legislativo-, del papel de la iglesia y del ejército, del civismo, del paro, del culto a los muertos, los mercados; el teatro nos hablará de los vencidos, de tolerancia, de libertad, o de las dudas del poder, nos llevará hasta los mitos de la Ilíada para reflexionar sobre el hombre maduro, evocará el sacrificio de Jimena entre amor y razón de estado, la OTAN y las autonomías, la soledad y la homosexualidad, las cárceles donde se encierra el hombre, nos confiará su fé y duda en el hombre: «El ser humano es torpe, deslumbrante, competidor, suicida, menestero, inagotable, ruin, magnífico, egoísta, insustituible. El ser humano es a la vez Caín y Abel. Eso es lo único con lo que contamos. Estamos hechos con la humilde y gloriosa madera de los sueños. Con la madera se puede construir un laúd o un patíbulo» (Gala, 1/2/81). La novela será otra forma de acercarse a los mismos problemas: El manuscrito carmesí nos llevará al encuentro de un vencido y presentará una maravillosa reflexión sobre la identidad andaluza; La regla de tres, nos conducirá a una íntima reflexión sobre el ser humano frente a la muerte, a su otoño y este sentimiento tan tremendamente humano, que invade toda su obra: el amor. En fin, cada poema, cada texto se volverá una entrañable reflexión sobre la condición humana, una condición fuertamente enraizada en lo cotidiano de cada español. Gala se presenta fundamentalmente como un humanista.

La visión de España que se va dibujando a través de sus artículos puede aparecer para algunos como pesimista, alarmista, sin embargo, Antonio Gala es todo excepto pesimista, ya que suele presentarse simplemente como un optimista bien informado, aunque si de vez en cuando exponga su decepción o su desencanto, éste no tarda en diluirse. Pero sabe cuán importante es la apuesta por la democracia y conoce su país, tantas veces «a punto de echar a perder todo y luego resulta así...». A España le gusta vivir peligrosamente, tiene tal urgencia de vida después de ese paréntesis de largo mutismo y represiones. 


\section{UN ESCRITOR COMPROMETIDO}

Por eso se puede afirmar que Antonio Gala es un autor comprometido con su época, por una parte a la manera de los intelectuales del regeneracionismo, atentos a la salud de su país: muchas veces Antonio Gala me apareció bajo los rasgos de un terapeuta a la cabecera de España, tierno y emocionante homenaje a este padre tan admirado, tomándole el pulso, cuidando de su etiología, las crónicas se vuelven boletines de salud publicados semana tras semana. En su relación íntima entre el autor y su país, se nota cierta complicidad similar a la del paciente con su médico de familia. Algo psicólogo, algo confidente, siempre atento, mirada exterior pero muy implicado afectivamente, concernido, Antonio Gala habla de su país con palabras de especialista.

Por otra parte, su compromiso es nítidamente «cívico»: su reflexión nace de una observación aguda de la realidad y totalmente libre de cualquier pertenencia a un partido o una opción: «Yo no pertenezco a ningún clan; ni a ningún grupo... ni al staff de un periódico siquiera, ni a una familia que me ampare... Yo soy la cabeza y todo lo demás de mi propia familia... No tengo más oficio ni más beneficio que mi mente y mi pluma...» (Gala, 9/3/80). Corresponde a una concepción original del papel del intelectual en la sociedad, una concepción mesiánica que defiende Antonio Gala y que participa de su éxito. En efecto, para él, el intelectual «es como un ojo crítico que observa alrededor de él lo que sucede, reflexiona sobre ello y lo hace ver a los que no tiene tiempo para reflexionar. Parece que el intelectual no tiene otra razón de ser que ésa...» (Dubosquet Lairys, 1989). El intelectual tiene una verdadera función social, participa como cualquier otra persona en la vida de la polis: político, panadero o médico,.. cada uno participa en la vida y desarrollo de la ciudad. No entra en su concepción ninguna sobre o subvaloración sino más bien otra noción, la del don que uno recibe y que configura entonces su destino. No se trata de una elección sino más bien de un fatum, un destino. Y de cierta forma ese papel le es reconocido. Por su independencia, que seguro muchos le envidian, supo conseguir una credibilidad y volverse una referencia civil, lo que confirma su elección como presidente de la Plataforma civil para la salida de España de la OTAN en 1986, y que aceptó aclarando que «no se trataba de unas elecciones partidistas, sino de un momento "cívico" fundamental.. la ciudadanía quería ser protagonista de una hora política importante. 
Quería asumir una responsabilidad inabdicable...» (Dubosquet Lairys, 1989). Por ello asumió la presidencia de un colectivo formado por una multitud de intelectuales, artistas y políticos «sin cartera» para reinvindicar la salida de España de la OTAN.... En efecto, el compromiso personal de Antonio Gala es siempre el compromiso de un individuo que asume totalmente su opción: «Soy un maniático de la responsabilidad. La responsabilidad tiene antes de cualquier aceptación, un sentido positivo de conciencia activa de las propias obligaciones» (Gala, 6/9/81). Cuando declara en 1985: «Soy homosexual, pero no ejerzo» no tiene nada de un scoop, ni de reivindicación de pertenencia a una comunidad o un ghetto, no tiene otra meta que concienciar a la gente sobre el peligro de la exclusión frente a una enfermedad, el sida, contra la cual todos tenemos que luchar solidariamente. Frente a la subida del paro, solidariamente con los huelguistas del 14 de diciembre de 1988, Antonio Gala escribe: «... Los españoles, que somos quienes sostenemos esta tierra nuestra y cuanto en ella vive, vamos a tomarnos veinticuatro horas para expresar, tácita pero directamente, nuestra opinión. No porque nos lo exijan, sino porque así lo hemos decidido. Veinticuatro horas no de lucha, sino de satisfacción compartida; no en una batalla de cartuchos, sino de comprensión y de sonrisas; no contra una tiranía - contra la que habría que ir con armas en las manos-, sino una jornada de afirmación democrática, es decir, una jornada en que unos con otros consentimos y unos y otros nos animamos...» (Martínez Moreno, 1994: 58). Esta carta que Antonio Gala dirigía a los huelguistas pone de realce toda una concepción del acto democrático, vivido en el seno de la sociedad española: la huelga no es sólo la expresión de una reivindicación sino también un encuentro, un intercambio, la expresión de un pueblo libre, consciente de su libertad. Antonio Gala apoyará y presidirá manifestaciones populares contra la Ley de Seguridad Ciudadana del ministro Corcuera, conocida como ley de «la patada en la puerta», ley declarada anticonstitucional por el Tribunal Constitucional en 1993 y que provocará la dimisión de dicho ministro. Tampoco se puede olvidar su participación al lado de los andaluces en su marcha para una existencia digna. Pero su posición será siempre la del ciudadano, consciente de su deber y responsabilidad, y aunque su actitud ética en estos movimientos participaron de su popularidad, sin embargo acentuaron el desfase con el mundillo político. Se suele decir que es una de las lenguas más afiladas que existen en España y él mismo confiesa que no tiene pelos en la lengua... En efecto, Gala no vacila en decir las «cuatro verdades del barquero». 
A propósito de su último estreno ${ }^{5}$, que no se hizo en Barcelona, afirmó que «los catalanes entienden mejor el polaco que el castellano», lo que desencadenó reacciones vivas hasta del mismo Jordi Pujol o de su denuncia del despido del director del Prado por no compartir la postura belicista del gobierno cuando la guerra del Golfo en febrero del 1991. Gala traduce los anhelos pero también las decepciones, los temores de toda una sociedad en plena mutación, en plena movida o ya posmovida, va más lejos, intenta educar, aclarar, transmitir cierto sentido crítico, cierta conciencia de responsabilidad. Lo que da, a veces, a sus escritos un matiz algo moralizante como en su Carta a los herederos. Así, se compromete: «Yo de mí sé decir que, en tanto pueda, trataré de escribir lo que en conciencia crea y debo, caiga el que se cayese, incluyéndome a mí...» (Dubosquet Lairys, 1989).

Claro que esta independencia le fue difícil de conseguir, y seguro de mantener: «Para elegir con objetividad, hay que mantener la independencia interior y exterior que nada - personas, ideologías, necesidades, prejuicios- nos hipoteque ni la cabeza, ni el estómago...» (Gala, $30 / 6 / 85$ ). Una independencia frente a todo poder que sea económico, religioso, político y militar que supone por lo tanto una fuerza, una ética y concretamente una soledad, una soledad sonora, que le es imprescindible: la última soledad que si «no defiende a toda costa, cualquier valor humano llegará a ser barrido...» (Gala, 12/5/73). Una soledad que le cuesta a veces tanto. El artículo «El transeúnte» lo ilustra intensamente, a continuación de una descripción minuciosa de una casa poblada por una mujer e hijos, el espejismo se disuelve para dar lugar a una infinita tristeza: «No me han dado otra opción. No conseguí levantar ese hogar, a cuyas puertas debo recuperar mi desolación de estar sin compañía y recoger el negro paraguas de la soledad...» (Gala, 10/10/95). Pero que protege celosamente: «Protejo mi soledad y la cultivo para que las íntimas compañías no me distraigan de esa otra e invisible y más amplia, para que mis minúsculos percances de compañero no me distancien de los percances colectivos...» (Gala, 6/6/82). Se transformará, entonces, en una soledad solidaria, a la manera de un Albert Camus, precio que eligió pagar para tener las manos libres de aplaudir o recusar lo que le parece plausible o recusable, y lo que le confiere esa referencia ética que muchos le envidian o le reconocen. Independencia que le permite tener hoy día, una tribuna abierta, en dos periodicos rivales o contrincantes: El País y El Mundo.

5 Los bellos durmientes, estrenada en el Teatro Coliseum de Santander, 18/8/94. 


\section{UNA PERSONALIDAD SINGULAR}

Detrás o quizá escondido detrás de una personalidad deslumbrante o irritante, provocadora y seductora, claramente atípica, que no deja insensible - las reacciones en su por o su contra son múltiples, si insistimos en las pruebas de su éxito popular, tambien pudiéramos encontrar ejemplos opuestos: una revista literaria muy conocida en Francia, consagró un número de 1995 a la creación española, no hubo ni una sola mención del autor.. o el famoso premio Limón que le otorgaron los periodistas-, aparece un hombre lúcido, un ser humano que comparte con todos una condición humana más o menos envidiable, un hombre con su pasado, sus heridas y jardín secreto, que se suele presentar — como un niño ya mayor de increíble sensibilidad don extremo y pesada cruz-, que atravesó mitad de siglo de tantos cambios. Un hombre cuya mirada atenta no perdió nunca esta espontaneidad, esta curiosidad y guasa que nos regala muchas veces la infancia. Nacido en una familia acomodada, subyugado por una personalidad paternal omnipotente, educado en una estética de la belleza («lo feo es malo») mimado por su ama que le enseñó la otra cara de la realidad ${ }^{6}$, su cultura y su expresión no perdieron nada de este doble aprendizaje. Sin duda es un solitario solidario a la manera de un Albert Camus, pero antes de todo un hombre, con sus cualidades y defectos, sus iras y sus debilidades, un hombre que reinvidica el derecho a pensar y expresarse libremente, un hombre fundamentalmente apasionado $y$ fundamentalmente independiente, un hombre que condena cualquier ghetto y quizá, lo que disfraza demasiado bien su imagen pública de dandy con bastón, una increíble timidez que desaparece detrás de un escudo de guasa, de ironía. Es interesante notar cuándo se forjó esta aparencia. Cuando estalló el éxito a finales de los años 70, Antonio Gala, de cierta forma organizó su imagen exterior como lo subraya Andrés Amorós: el bastón usado más por "estática que estética» (Gala, $15 / 11 / 81$ ) como le gusta subrayarlo, las cadenas en el cuello, cierta teatralización en los modos y forma de expresarse, consolidó su origen andaluz, una imagen en la cual participó muchísimo la prensa y

\footnotetext{
6 Un cuerpo de estar que participó de su formación andaluza. En efecto si el autor nació en Brazatortas (Ciudad Real) vivió a partir de sus dos años en Córdoba, así que su origen andaluz no se avala por contar en un registro civil, sino por una legítima identificación sentimental, intelectual y vivencial con la tierra andaluza cuyo personaje principal de su infancia fue su ama.
} 
la televisión donde apareció a menudo para presentar sus Paisajes con figuras o Si las piedras hablaran. Una imagen que le permitía sin duda delimitarse un espacio de libertad para su creación, y de protegerse.

\section{UNA ESCRITURA SINGULAR}

Como hemos visto, esta fuerte personalidad ha contribuido a esta identificación del autor con un amplio público. En efecto, Antonio Gala asocia a una reflexión intelectual, una sensibilidad aguda y un manejo extraordinario del castellano. Además, para establecer la relación con su público, definió una exigencia primaria a cualquiera de sus actos: la fidelidad. Fidelidad a una época y sus preocupaciones, como acabamos de ver a través del estudio de los temas; fidelidad a una cultura que comparte con sus lectores y cuya clave es el idioma: «Hay una confianza como miembros de un mismo cuerpo que es eso lo que nos confirma el idioma, el idioma no es nada más que algo absolutamente común, lo más común que podemos tener, la expresión» (Dubosquet Lairys, 1989).

La palabra, esencia misma de la escritura, humilde herramienta del escritor, es una «vía de conocimiento, de raciocinio, de compenetración, de herencia compartida» (Dubosquet Lairys, 1989). La escritura del autor se volverá una constante búsqueda de identidad, de autenticidad: «¿habrá algunas (señas) más hondas que los orígenes de nuestro estilo de nombrar, de señalar, de relacionar las cosas con los seres?» (Gala, 17/3/85). Escribir es antes de todo compartir, compartir palabras, ideas, una cultura y además es creación, participación activa en esta cultura viva.

Para eso, Antonio Gala no renunciará a otra fidelidad previa, la fidelidad a sí mismo. Siempre se definió como poeta: «la poesía no es para mí una forma de expresión sino una vía de conocimiento. Y en definitiva, una entrega final y una fructificación» (Soler Serrano, 1984: 92). La poesía empapa cada una de sus creaciones, y corresponde a la concepción de la poiêsis de Platón o sea que la creación es como un líquido que toma la forma del recipiente en el que se vierte. Para Gala la poesía a veces se concreta en el poema, pero no siempre: «a veces hay como una fisura y ese gas que es la poesía se escapa y lo tiñe todo, 
entonces hay poesía de drama, poesía de relato, poesía hasta de artículo de periódico...» (Dubosquet Lairys, 1989). La poesía se vuelve para él, una actitud vital.

Por fidelidad a sí mismo tampoco renuncia a lo que es por su educación, por su origen social, y así lo subraya Juan Cueto: «Los discursos de Antonio Gala, los mayores como los menores no proceden ni forman parte de la cultura popular. Pertenecen con todas las de la ley a la cultura culta, aunque al cabo de un proceso complejo hayan llegado a ser extraordinariamente popular sin ceder una línea ni conceder una metáfora de su primitivo estilo.»(Gala, 1983a). Así el latín o la terminología más específica como por ejemplo la «sinecdoque» o una invitación a reflexionar sobre el sentido mismo de las palabras («pontífice: el que hace puente») están presentes.

No disimula tampoco una sensibilidad extrema que se va revelando a lo largo de su obra, quizá todavía más en su poesía y palpita en toda su escritura: «Yo no me escondo.... yo voy con la intimidad a flor de piel...» (Santa Cecilia, 31/4/1985: 6-7). Su interlocutor privilegiado es el hombre, el ser humano en busca de su destino, de su propia realización, en una sociedad en plena metamorfosis, un ser perdido en una sociedad donde la uniformización es cada vez más fuerte. El genio de Antonio Gala será devolver a este ser una identidad, una individualidad, y transformarlo en su interlocutor privilegiado. Eligió hablar del ser humano, y para eso eligió el que más conoce, el que anda buscando a lo largo de sus creaciones: él mismo, de ahí esta sensación de intensa intimidad que se va acentuando a lo largo de sus crónicas o escritos, pero que al mismo tiempo se enriquece de manera paradójica de universalidad: lo íntimo se vuelve público y lo público se vuelve íntimo. Esta concepción de la escritura nos recuerda a un paisano mío, Victor Hugo, quien, presentando sus Contemplations, escribía: «Quand je vous parle de moi, je vous parle de vous» y que encuentra su propio eco en estos versos, escritos en 1964, de $L a$ Deshora:

« He hablado yo de mí?

¿Hasta ahora acaso

habré hablado de mí?

No, porque a cada uno

o todo lo más, dije

lo que nunca, he sabido de mí mismo

cosas vuestras por tanto...» 
Antonio Gala lo traduce a la perfección cuando escribe: «es posible que no haya hecho más que escribir sobre mis propios sentimientos - es decir personales- los sentimientos que yo expreso. Si alcanzan a mis lectores unas veces por vías cordiales, otras por vías intelectuales, otras por vías viscerales serán porque las comparten (Gala, $31 / 8 / 85)$. Estas tres vías son también, según el autor, tres caminos que conducen a su propio conocimiento.

Está plenamente convencido de la necesidad de comunicación de cada ser en la sociedad, porque pertenecen a una comunidad de individuos tan semejantes y tan diferentes, cada uno con su propia personalidad, pero con esa ansia de ser, de vivir, de existir, siendo cada uno único y al mismo tiempo solidario. Así a través de cada texto, Antonio Gala va al encuentro de cada uno de sus lectores, devuelve a cada uno su individualidad en una sociedad que tantas veces uniformiza, reivindica el derecho a ser diferente, a expresar el YO. Desde su experiencia personal, Antonio Gala va hacia la universal, y por eso se sitúa directamente en el terreno de los sentimientos: «Es que hay una hondura recondita y sagrada en que los seres humanos nos identificamos unos más y otros menos. Hay una zona inerme, desnuda, solitaria, que los seres tenemos en común; en la que coincidimos por encima del tiempo y de las geografías...» (Gala, 31/8/85).

Para establecer esta comunicación, tuvo que encontrar el tono más justo, adaptar, sin traicionarla, su expresión: «Yo aspiraba a dirigirme en voz baja a un solo oído y me he visto obligado a dirigirme a millones de oídos: era preciso cambiar la voz y los modales» (Gala, 11/12/1983). Buscará entonces en la cultura compartida, el camino más directo con su público, sin renunciar a lo que es.

Por su fidelidad a sus raíces, Antonio Gala nos invita al viaje hacia las honduras del alma española, viaje al ritmo de las palabras, de sus sonoridades y sentidos. Antonio Gala, el andaluz se siente garganta prestada de todo un pueblo. Queja, grito o canto, su escritura traduce su hispanidad, su fidelidad a sus raíces andaluzas.

«El escritor verdadero es el que, cuando escribe, transcribe el subconciente y lo recordado colectivo, el que desaparece y se transforma en vehículo; el que sabe que es una garganta prestada y una mano prestada..» (Urbano, 31/3/1986). Por esta concepción misma de la escritura, hablaremos de un componente andaluz, de una escritura andaluza.

Recuerdo una anécdota, durante nuestro primer encuentro, cuando Antonio Gala me declaró: «Si yo por ejemplo, no tengo la misma cultura 
que un campesino andaluz, yo soy el equivocado...» Incrédula, algo divertida, miraba a este hombre que me citaba a Platón, evocaba a Rousseau o Pascal, en esta magnífica casa madrileña... Sin embargo, poco poco, entendí lo que significaba profundamente esta declaración, elemento clave en el caso del autor, preocupación constante, casi obsesiva como lo vemos en esta confesión a la Dama de Otoño: «Conoces mi preocupación por el lenguaje, el temor a perder el contacto con la única fuente verdadera del lenguaje que existe. Y no me refiero a ningún vocabulario artificial, transeúnte, de vaivén más o menos largo, sino al destelleante, caleidoscópico, irisado y fértil idioma popular...» (Gala, 18/3/1984).

Para Antonio Gala hay dos tipos de culturas: una congenital, que no poseemos pero que nos posee y la otra que no es más que el resultado de un aprendizaje, de un afinamiento del conocimiento. La primera es visceral, es presencia más que razonamiento. Antonio Gala es un ser refinado, culto, de formación universitaria, pero permanece profundamente atado a esta cultura innata, visceral, sin renegar a la otra aprendida, pretendiendo rendir homenaje a esta cultura previa, la que comparte con el campesino, el pueblo...

Más que en la expresión, es en la concepción misma, donde aparece la identidad andaluza del autor, pudiéndose comparar su creación a la del cante jondo. Así, si el cantaor es garganta prestada que se submerge y bebe en las fuentes de la memoria colectiva y de la experiencia cotidiana, los acentos de su queja, el escritor es según Antonio Gala: «Una esponja, dejándose inflar para luego, en cierto sentido, exprimirse..» (Dubosquet Lairys, 1989) .

La escritura es, entonces, el resultado de una interiorización: impregnarse de la realidad, de esta cultura que nos rodea, digerirla con sus propios jugos gástricos, y luego restituirla, exteriorizarla, representarla y desaparecer detrás de su mensaje, no ser más que la mano prestada. La escritura como el cante, es un arte, una creación solitaria, arte introvertido por excelencia, porque se vive más que se intelectualiza: ««La creación es una partenogénesis. La soledad en ella es esencial. La habrán precedido toda clase de promiscuidades, de invasiones, de confusiones, pero ella es una puesta en limpio, un acto de moderación, un ensismismamiento...» (Gala, 14/11/1982). La identificación vendrá después de la presentación del mensaje, jaleo o palmas, la adhesión será la seña del reconocimiento.

Así, la noción de solitario solidario toma aquí toda su dimensión. El escritor o el cantaor no hacen más que cumplir con su destino de intér- 
prete solitario, de voz-testigo de toda una cultura, destino al que ninguno de los dos pensarían escapar.

Si el cante jondo es la invención de un pueblo que da a su queja hermosura y elegancia, si es obra de mestizaje de cantos diferentes: «una trenza de esparto y de seda y de escalofríos que vienen de los cantos sinagogales judíos y viene del canto llano, eclesiástico, bizantino y de los gritos y de las melismas gitanas...» (Dubosquet Lairys, 1989) fruto de diferentes ghettos, canto de iniciación y de rebeldía, expresión que nace desde las honduras del alma andaluza, los escritos de Antonio Gala son ellos también, cantos dedicados al hombre y a la condición humana, que nos hablan de los grandes problemas del español de hoy, del ser humano, de sus penas y de su tierra, de sus amores perdidos o rotos, de la felicidad y de las lágrimas, de la vida y de la muerte, como esas coplas andaluzas, con palabras del pasado y palabras del presente. Lo íntimo se vuelve público, lo público, íntimo, la vida fuente de creación y la creación fuente de vida.

La cultura del campesino andaluz que reivindica Antonio Gala no es sólo palabras sino más bien una actitud vital frente a los acontecimientos cotidianos, triviales o no; es al mismo tiempo una manera de contar la vida, como testigo y actor con esta pizca de ironía, especie de escudo frente a la realidad, que permite alejarse, distanciar la gravedad de lo cotidiano.

Este sentido, el humor, que pocas veces abandona a Antonio Gala, que según el autor es herencia andaluza, herencia de una tierra fronteriza ¿no sería, suprema elegancia, vestir su pena y su angustia de una sonrisa?: «Es que existe un pudor último debajo del impudor inmediato: esa es una de las características extrañadísimas de lo andaluz...» (Gala, 5/10/80); un humor que se vuelve arma, y se transforma a veces en ironía mordaz. Si permite romper con el carácter solemne de una proclamación intelectual, es una forma diferente y original de exponer alguna temática. Una ironía que José María Rodríguez Méndez define así: «una ironía que perdió su raíz intelectual y dialéctica a través de la mística sufí para convertirse en el estallido de la traca, el correr de la pólvora, el fuego del artificio sobre el paisaje de los mirones embobados ante las grandes hazañas. La ironía de Antonio Gala rompe sobre el paisaje realista en un olor de azufre demoniaco con sabor a magia inesperada, poniendo en evidencia la fragilidad de los grandes problemas humanos. A la larga su denuncia, su crítica demoledora - totalmente demoledora - puede resultar más constructiva, por definitiva y clausurante, que las actitudes meramente interpretativas. El uso de la ironía poética de Antonio Gala supone la imposibilidad de 
sustituir y la necesidad de empezar algo nuevo y distinto» (Rodríguez Méndez, 1970). La causticidad estalla en sus páginas, y participa de esta pintura del mundo que le rodea, con este matiz caricaturesco de un Goya, pero la magia del pintor como la del escritor da al mensaje, fuerza, poder, para encontrar un eco en un lector o en un espectador. El humor es otro factor de complicidad, de juego, escudo frente a una realidad a veces agobiante, que permite relativizar, salirse de apuros con más elegancia. Antonio Gala y su amigo José Infante no vacilan en afirmar que «el amor y el humor son las únicas tablas de salvación que tenemos y ambas deben ser las que ordenen todos nuestros gestos...» (Infante, 1995: 13).

Para Antonio Gala, la fidelidad a su pueblo pasa por la fidelidad a sus palabras, a su manera de designar las cosas que le rodean, de traducir sus impresiones propias y sus sentimientos. Este idioma palpitante, lo encontramos bajo la exhuberancia verbal del autor. El idioma coloquial es para él, fuente inagotable de imágenes, expresiones, formas adecuadas para acompañar su mensaje como por ejemplo:

\section{- Los sufijos:}

Aumentativos o diminutivos, con función o no peyorativa están muy presentes en el lenguaje coloquial español. Su reutilización en un texto escrito da una tonalidad particular al enunciado: «hociquillo», «ojillos», los «listillos de la política», «la iglesia decaidita» o «la cultura terciadita», o los aumentativos como «culones mentales» $o$ «señoritinga viejacona». Como lo escrito quita todo del ademán o de la entonación, aquí será la complicidad entre el autor y su lector la que le va a restituir el matiz irónico al mensaje. A veces, mezcla esta complicidad, nacida de una herencia lingüística, con la herencia histórica: «antecristazo de Almanzor», o una circunstancia política cuando habla de «Pífano de abril» con una alusión al ministro de aquella época Abril Matorell ...

\section{- Juegos de palabras, juegos de espejos:}

Maestro en el arte del juego de palabras, Antonio Gala los utiliza, los transforma, los asocia a contratiempo, a contraempleo, revelando el disfrute del poeta en sugerir, en emplazar o desplazar las sonoridades, las imágenes, los mensajes: 
Jugando por ejemplo con el sentido: «Le pregunté al alcalde si había hecho algún artilugio, algún andamio para facilitar el ayuntamiento, el tuyo Troylo, no el de él...» (Gala, 12/8/79). Nueva creación con palabras maletas o palabras baúl: «protejoder», que traduce a las mil maravillas el peso del paternalismo, y que sin caer en lo vulgar, da la impresión de encanallarse. Otro ejemplo: la alusión a la «Teleafónica» que resume a la perfección los problemas de funcionamiento de este medio de comunicación.

Jugando con los sonidos, nos propone retruécanos o lapsus burlescos: «yo por emoción y tú por micción, nos convertimos en afluentes del Guadalquivir», o: «a la juerga la hemos sustituido por la huelga», o más bien: «no llevo bastón por estética sino por estática», «los hombres hechos y derechos o hechos y deshechos», «ni son todos lo que están, ni están todos los que nos son...»; juego de gama: se sirve de toda la paleta de niveles de lenguaje, yendo del más culto al más popular o viceversa: «Decir perro para referirse a los perros, ademés de una sinecdoque es una cabronada» o al referirse a los tribunales eclesiásticos habla de: «concupiscentemente meticones.»

Y encuentra en la calle el término adecuado a cada situación: «soluciones garbanceras», pelagato se ve transformado en «pelagallo.»... Utiliza también otra riqueza que es la comparación: «hablar con boca de ganso», y crea así una mujer «pesada por delegación» para describir una funcionaria con agudo sentido de la jerarquía y de su poder. El hocico de Troylo es «frío como el culo de una mujer o las manos de un barbero». O también, «pasamos de cogérnoslas con papel de fumar a generalizar el violeo», en la cual la elipse de la palabra colita, acentúa todavía más el estallido de la pudibundez al final de los años 70 . No se trata entonces de puntuar el discurso de expresiones chelis o pasotas, sino que Gala quiere ser eco de la realidad, de la lengua de la calle.

Antonio Gala se divierte golosamente con las palabras, y disfruta muchísimo sabiendo que de repente en un razonamiento bastante intelectual hay una caída absolutamente popular, con una frase desgarrada y arremangada del pueblo, un pueblo que se reconoce, que se identifica plenamente con el escrito. Así utilizando toda la gama que le propone el idioma, yuxtapone lengua popular y lengua académica, porque es un intelectual, y no puede renunciar a lo que es sin traicionarse; pero lejos de ser un obstáculo, se vuelve enseñanza, «partage» (compartir) como lo expresa: «para que de alguna manera el pueblo que maneja la misma lengua que yo, sepa qué lengua tan hermosa manejamos los dos 
juntos...» (Dubosquet Lairys, 1989). Compartir esta lengua que le apasiona, tal parece ser su deseo más profundo y hacerlo lo más inteligible posible sin bajar peldaños, no bajando él sino intentando tirar de los demás, que es una forma de «elitismo mayoritario» como dice Juan Cueto (Gala, 1983a).

En esta búsqueda de mayor fidelidad a su pueblo, hay otros factores que intervienen de manera deslumbrante, como por ejemplo la utilización que él hace de los refranes y expresiones populares. Verdades de experiencia o consejo de sabiduría práctica y popular comunes a todo grupo social, los refranes y expresiones populares están siempre presentes en su obra, y lo justifica así: «A mí me parece que las expresiones que quedan y que el pueblo ha manejado durante siglos y que permanecen son porque tienen en sí mismas un valor...» (Dubosquet Lairys, 1989).

Sentencias o fórmulas elípticas generalmente ilustradas, los refranes y expresiones abundan en los textos del autor tal como lo hacen en el lenguaje coloquial español. Corresponden sin duda a un homenaje por parte de Antonio Gala al idioma popular y a su sabiduría. Introduciéndolos en un texto eminentemente literario acceden a una culta notoriedad, pero además, su carácter de ilustración popular rompe a veces el carácter solemne de proclamacion intelectual que pueda tener el texto y tiene más impacto que cualquier razonamiento didáctico: «pedir peras al olmo», «el que quiere algo ha de mojarse el culo», «donde hay harina, todo es mohína» 0 «la jodienda no tiene enmienda»... El autor no se contenta con citarlos, a veces los transforma, como por ejemplo: «El perro del hortelano que ni come las berzas ni las deja comer al amo»; «pasar las duras y las maduras», se vuelve «pasas las duras y maduras», dando a este refrán un final más positivo...; o los crea: «tomar el consomé después del postre nunca es buen final». Para sacar toda la sal de tales expresiones con todos estos modismos es fundamental la complicidad de una cultura común. El lector encuentra sus propias referencias, se han dicho cosas que él sabe perfectamente, que ha oído siempre a su abuela, a su madre, a su tía, a su hermano mayor. Estos puntos de referencia sostienen el discurso de Antonio Gala, como por ejemplo: «por si las moscas», «eramos poco y parió la abuela», «no es Pascua en diciembre»... Son tantos ganchos de abordaje, guiños; pero también, a veces, ocasión de reflexión sobre su propio origen, su cultura o la riqueza de lo que constituye en fin la cultura española: «"perro": aquí, perro se llamó a los moros y a los judíos para enfrentarlos, y aún ahora se le llama a una persona malvada y ruin». «Perro» es el engaño o perjuicio que se ocasiona a alguno con un trato o ajuste, y es lo muy malo, atroz o indigno. «Dar perro» es dar plantón o 
causar vejación, y «dar perro muerto» es gastar una broma en exceso pesada. «Dar uno a perros» es darse a todos, los demonios. «Echar a perros algo» equivale a malbaratarlo. «Cara de perros» es la del que no perdona...» (Gala, 14/6/79).

El lenguaje de la calle está presente, incluso en sus excesos, cuando Antonio Gala se siente provocador: «sin liarnos a hostias» 0 «por cojones» 0 «mentarle a la madre»... Pero nunca de manera inútil, así cuando por ejemplo, sorprende a la Real Academia en pleno delito de pudibundez en su definición de hacer puñetas: según la Real Academia es «una labor fatigosa que consiste en confeccionar encajes para puños de toga...» «Una mierda» añade el autor y confía a la Dama de Otoño que siempre le ha divertido hablar en frío de lo caliente, pero le gusta llamar las cosas por su nombre: «no tengo pelos en la lengua» y lejos de reivindicar un gusto especial por la vulgaridad, elige a un digno maestro del pasado: Quevedo, para esclarecer lo que la hipocresía y el puritanismo dejaron empañado: «Puñetero, escribe Quevedo es amancebado con la mano...» (Gala, 12/2/84). Claro, que se divierte mucho, no sólo denuncia un delito de pudibundez, sino que además propone así una revancha de la verdadera competencia lingüística, la del lector nativo, no instruido, sobre el lingüista profesional prisionero de su puritanismo. Porque en el sexo ¿no sería el terreno por excelencia donde se encuentran la mayor finura y la mejor sabiduría popular? Pero, si se muestra crítico para con la Real Academia, sabe sin embargo que es un código de referencias necesarias.

Para su testimonio, Antonio Gala necesita el lenguaje: «el lenguaje verdadero es el lenguaje popular...»; " entonces en mí», dice, se da esa dualidad del lenguaje culto con ése, me parece que se dice un lenguaje saltarín y riscoso, es decir una cosa que está mezclando las dos cosas, está combinando el lenguaje verdaderamente llano con el conocimiento y el lenguaje culto...» (Dubosquet Lairys, 1989).

Dar la impresión de un idioma popular, o mejor aún agarrar lo que el lenguaje popular tiene de más expresivo, más rápido, más directo y enriquecerlo después con expresiones rebuscadas, cultas de las cuales no puede desprenderse, ya que forman parte de su ser, aquí está sin ninguna duda, una de las claves esenciales de su escritura.

En Antonio Gala, el loco enamorado de las palabras, encontramos al poeta enamorado de su melodía, de su símbolo, al dramaturgo con sus palabras ganchos, al articulista atento a su mensaje, al novelista apasionado. El testimonio que propone Antonio Gala a través de sus 
textos, de su país y de su pueblo, respetando las peculiaridades de cada uno, es el de una riqueza extraordinaria. No se limita a su Andalucía sino que va extendiendo su radio a la geografía impar de toda España: escritura fonética o citas desde Rosalía de Castro a Salvador Espriu, para su lector, sea del Sur o del Norte y que puede divisar algo de su paisaje, de lo que le es propio: paisaje, acento, expresión, máxima o copla. Las obras de Antonio Gala tienen algo de un viaje a través de la geografía ibérica y son un vibrante homenaje a la riqueza que supone la multiplicidad de sus culturas. Por su precisión, y por la extrema localización de sus escritos, Antonio Gala sensibiliza, toca en lo más hondo de cada uno en lo que le es más íntimo y paradójicamente logra así una forma de universalidad. Ser español es ser lo más andaluz posible. A través del espejo de las palabras, se refleja España en su complejidad, su diversidad y su unidad.

A través de este breve estudio, hemos intentado definir los diferentes elementos que entran en esta alquimía que reúne Antonio Gala con su público: una época clave en la historia de un país, el papel de los media, unos temas profundamente enraizados en la realidad cotidiana, una reflexión sobre preocupaciones comunes, pero todos estos elementos no le diferencian tanto de muchos otros escritores, así que si estos elementos participan de su éxito, habrá otras explicaciones. Primero destacaremos la coherencia temática de toda su obra, cuyo eje principal es el ser humano, y por otra parte podremos subrayar el concepto de fidelidad omnipresente a lo largo de su creación: «A lo único a que yo he aspirado, siguiendo el viejo consejo de Shakespeare es ser fiel a mí mismo porque sabía que sin esa fidelidad previa jamás conseguiría las otras fidelidades a mi momento y a mi pueblo que son las que hacen de verdad a un escritor» (Dubosquet Lairys, 1989). Una fidelidad que pasa por los temas, pero también por la expresión, clave de la identificación. Antonio Gala supo escuchar, sentir y vestir con palabras las mínimas preocupaciones de la condición humana, escribiendo para una muchedumbre solitaria, nacida de la sociedad occidental consumista. Adaptó su voz a su auditorio, cada vez más importante, sin renunciar nunca a lo que es: un intelectual, de formación universitaria. Su creación está obsesivamente preocupada por la cultura popular: «El escritor verdadero es el que, cuando escribe, transcribe lo subconsciente y lo recordado colectivo: el que desaparece y se transforma en vehículo; el que sabe que es una garganta prestada y una mano prestada...» (Urbano, 31/3/86). Una cultura popular que vive, palpita y sostiene sus escritos, y se vuelve fuente de placer y complicidad, cemento de la identificación, como lo demostramos por el estu- 
dio de la singularidad de su escritura. Antonio Gala reintroduce la cultura popular, la expresión popular como referencia, y le devuelve «ses lettres de noblesse»... acto relevante en nuestras sociedades, $y$ mundos culturales, donde lo popular tiene siempre algún matiz peyorativo basta evocar la cultura popular o más bien el éxito popular, como si se quisiera rebajar, o de cierta forma marginar este tipo de creación-. En cierta medida, la picaresca compartió algo de esta experiencia: nació en margen de la creación, en la España de Siglo de Oro, de Carlos I y de la Contrarreforma, surgió como una verdadera contra-literatura donde el pícaro tomó la palabra, empleó el yo para denunciar una sociedad corrupta. Sin querer comparar a Antonio Gala con el pícaro, no se puede negar que su trayectoria creativa se inscribe en una tradición literaria hispánica, que va desde la picaresca a la concepción de los escritores españoles del 98 y el 27 obsesionados por el problema de España. Coherencia, fidelidad, ética e independencia, matizadas de cierta insolencia o provocación asociadas a una escritura brillante y culta, de gran refinamiento en el fondo y en la forma, que suele manejar temas específicamente literarios, y de una gran sensiblidad poética hacen de Antonio Gala un escritor aparte, que desgraciadamente (¿o no?) fue reconocido por el pueblo al que se quiere identificar antes de serlo por lo que podemos llamar la intelocracia. Lo que plantea un problema de fondo y abre un debate: los fines y metas de la creación literaria. Como hemos visto, la opción galiana se atiende claramente a la de un intelectual comprometido con su sociedad, opción a la que es profundamente fiel.

\section{Referencias bibliográficas}

a) Obras:

AguirRe, F. (1995). Espejito, espejito. San Sebastián de los Reyes: Universidad Popular.

Amorós, A. (1983). Diario Cultural. Madrid: Espasa Calpe.

DUBUSQUET LAIRYS, F. (1989). Antonio Gala, un regard sur l'Espagne des années 80. Tesis de doctorado, Universidad de Rennes 2 (Francia).

Gala, A. (1981). Charlas con Troylo. Madrid: Espasa Calpe.

- (1983a). En propia mano. Madrid: Espasa Calpe.

- (1983b). La trilogía de la libertad: Petra Regalada. La vieja señorita del paraíso. El cementerio de los pájaros. Madrid: Espasa Calpe.

- (1985). Paisaje con figuras. Madrid: Espasa Calpe. 
- (1986). Cuaderno de la Dama de Otoño. Madrid: El País.

- (1987). Séneca o el beneficio de la duda. Madrid: Espasa Calpe.

- (1988). Dedicado a Tobias. Barcelona: Planeta.

- (1994). Los bellos durmientes. Madrid: Espasa Calpe.

INFANTE, J. (1994). Antonio Gala, un hombre aparte. Madrid: Espasa Calpe. Martínez Moreno, I. (1994). Antonio Gala, el paraíso perdido. Madrid: CSIC.

Romera Castillo, J. (1996). Con Antonio Gala (Estudios sobre su obra).

Madrid: Universidad Nacional de Educación a Distancia.

b) Artículos:

GaLA, A. (12/5/1973). «Texto y pretexto: De la soledad». Sábado Gráfico.

- (14/6/1979). «Charlas con Troylo: Lengua de perro». El País Semanal.

- (12/8/1979). «Charlas con Troylo: La Tornada». El País Semanal.

- (9/3/1980). «Charlas con Troylo: Los independientes». El País Semanal.

- (5/10/1980). «Charlas con Troylo: El severo impudor». El País Semanal.

- (1/2/1981). «En Propia Mano: Invitación a la esperanza». El País Semanal.

- (6/9/1981). «En Propia Mano: Los premios». El País Semanal.

- (15/11/1981). «En Propia Mano: El último bastón». El País Semanal.

- (6/6/1982). «En Propia Mano: Admiraciones egoístas». El País Semanal.

- (14/11/1982). «En Propia Mano: Reflexiones sobre un amanecer». El País Semanal.

- (11/12/1983). «Cuaderno de la Dama de Otoño: Hablar de mí». El País Semanal.

- (12/2/1984). «Cuaderno de la Dama de Otoño: Estar en babia». El País Semanal.

- (18/3/1984). «Cuaderno de la Dama de Otoño: Un día más, un día menos». El País Semanal.

- (17/3/1985). «Cuaderno de la Dama de Otoño: La herencia malgastada». El País Semanal.

- (30/6/1985). «Cuaderno de la Dama de Otoño: El proceso». El País Semanal.

- (31/8/1985). «Cuaderno de la Dama de Otoño: Los sentimentales». El País Semanal.

- (24/8/1986). «Dedicado a Tobías: La novia de Reverte». El País Semanal.

- (10/10/1995). «La casa sosegada: El transeúnte». El País Semanal.

RodRíGuez MÉndez, J. M. ${ }^{a}$ (1970). «Antonio Gala y su realismo irónico».

En VV.AA., Antonio Gala, Madrid: Taurus. 
SANTA CECILIA (31/8/1985). «La docilidad rebelde de Antonio Gala». El País, sup. Artes, 6-7.

Soler Serrano, J. (1981) . «El poderío verbal de Antonio Gala». En Al fondo de la A a la Z. Barcelona: Plaza y Janés.

UrBaNO, P. (31/3/1986). «Antonio Gala: Felipe no ha sido fiel a su pueblo». Época. 